\title{
Pregnancy and Obstetrical Outcomes in Women Over 40 Years of Age
}

\author{
Schwangerschaft und Geburt bei Frauen über 40 Jahre
}

Authors

Affiliations
A. Dietl ${ }^{1}$, S. Cupisti ${ }^{2}$, M. W. Beckmann ${ }^{2}$, M. Schwab ${ }^{3}$, U. Zollner ${ }^{3}$

${ }^{1}$ Department of Obstetrics and Gynecology, University of Freiburg i. Br., Freiburg i. Br.

${ }^{2}$ Department of Obstetrics and Gynecology, University of Erlangen, Erlangen

${ }^{3}$ Department of Obstetrics and Gynecology, University of Würzburg, Würzburg
Key words

- pregnancy

- advanced maternal age

- gestational diabetes

- hypertension

- cesarean section

Schlüsselwörter

- Gestationsdiabetes

- Schwangerschaft

- Reproduktionsmedizin

- Geburt

- Plazenta

- Präeklampsie

\section{received $\quad 7.12 .2014$ \\ revised 28.4.2015 \\ accepted 29.4.2015}

Bibliography

DOI http://dx.doi.org/

10.1055/s-0035-1546109

Geburtsh Frauenheilk 2015; 75 :

827-832 @ Georg Thieme

Verlag KG Stuttgart · New York ISSN 0016-5751

\section{Correspondence}

\section{Anna DietI}

University Hospital Freiburg i. Br. Department of Obstetrics and Gynecology Hugstetter Straße 55 79106 Freiburg i. Br. dietlanna@gmail.com

\section{Abstract}

\section{$\nabla$}

Introduction: Delayed childbearing is increasing and advanced maternal age has been associated with an increased risk of obstetrical complications. The purpose of this study was to evaluate pregnancy outcomes in women with advanced maternal age ( $\geq 40$ years).

Methods: Maternal and obstetrical data were collected from the Department of Obstetrics and Gynecology of the University of Wuerzburg for the period from 2006 to 2011. In this retrospective analysis we compared the outcomes for women aged $\geq 40$ years $(n=405)$ with those of three younger subgroups (I: < $30 \mathrm{y}$; II: 30-34 y; III: 35-39 y). Results: Pregnant women older than 40 years had more chronic diseases such as hypertension, needed medical treatment more frequently and had a higher thrombosis risk. Pregnancy-induced diseases such as gestational diabetes, preeclampsia and pregnancy-associated hypertension occurred more often in women $\geq 40$ years of age. Compared to mothers who were younger than 30 years, primiparous women $\geq 40$ years had a more than four times higher overall cesarean section rate and four times higher elective cesarean section rate. Furthermore, they required longer hospital stays, both after cesarean section and after vaginal delivery. The preterm birth rate $(\leq 32$ weeks of gestation) was similar across the different age groups.

Conclusions: The outcomes of pregnancy and childbirth and for newborns born to women $\geq 40$ years did not vary significantly from those of younger women if the following conditions were met: a) pre-existing chronic diseases were treated medically and dietetically; b) pregnancy-induced morbidity was monitored regularly and controlled medically; c) women attended regular prenatal check-ups; d) a healthy lifestyle was adhered to during pregnancy, and e) delivery occurred in a perinatal center.

\section{Zusammenfassung \\ $\nabla$}

Einleitung: Der Trend zur späten Mutterschaft steigt und im Zuge dessen wird fortgeschrittenes mütterliches Alter mit steigendem Risiko für geburtshilfliche Komplikationen verbunden. Ziel dieser Arbeit war es, den Schwangerschaftsausgang bei Frauen im fortgeschrittenen mütterlichen Alter ( $\geq 40$ Jahre) zu untersuchen.

Material und Methoden: Mütterliche und geburtshilfliche Daten zwischen 2006 und 2011 der Geburtshilflichen und Gynäkologischen Abteilung der Universitätsfrauenklinik Würzburg wurden analysiert. In einer retrospektiven Untersuchung wurde die Altersgruppe $\geq 40$ Jahre ( $\mathrm{n}=405)$ mit 3 anderen Subgruppen (I: < 30 Jahre; II: 30-34 Jahre; III: 35-39 Jahre) verglichen.

Ergebnisse: Schwangere Frauen älter als 40 Jahre litten häufiger an chronischen Erkrankungen wie Hypertonie, hatten häufiger behandlungsbedürftige Allgemeinerkrankungen und hatten ein höheres Thromboserisiko. Schwangerschaftsinduzierte Erkrankungen wie Gestationsdiabetes, Präeklampsie und schwangerschaftsinduzierte Hypertonie kamen häufiger bei Frauen $\geq 40$ Jahre vor. Erstgebärende $\geq 40$ Jahre hatten ein mehr als 4-mal höheres Risiko per Sectio und ein 4-mal höheres Risiko per elektiver Sectio zu entbinden als Frauen < 30 Jahre. Des Weiteren blieben diese Frauen sowohl nach Sectio- als auch nach Spontanentbindung länger im Krankenhaus. Die Frühgeburtenrate $(\leq 32$.SSW) verteilte sich gleichmäßig auf die verschiedenen Altersgruppen.

Diskussion: Das Outcome der Schwangerschaft, Geburt und des Neugeborenen einer Frau $\geq 40$ Jahre unterscheidet sich nicht signifikant von dem einer jüngeren Schwangeren, wenn folgende Voraussetzungen erfüllt sind: a) vorbestehende chronische Erkrankungen sind medikamentös und/oder diätetisch eingestellt, b) schwangerschaftsinduzierte Erkrankungen werden regelmäßig überwacht oder medikamentös eingestellt, 
c) die Schwangerschaftsvorsorge wird regelmäßig wahrgenommen, d) ein gesunder Lebensstil wird auch während der Schwangerschaft beibehalten, und e) die Entbindung erfolgt in einem Perinatalzentrum.

\section{Introduction}

\section{$\nabla$}

The last three decades have shown an increasing trend to delay childbearing beyond the age of 40 . The reasons for this development could be the increasing use of reproductive techniques [1] but also the enormous changes in work and society, which include higher levels of female employment and educational attainment and higher numbers of women working in higher level jobs. Late financial independence, fixed-term employment contracts for career entrants, the low per capita income of young families, the limited numbers of part-time positions, and the lack of flexible working hours make it harder to reconcile work and family life. The lack of affordable childcare can be a further problem for young working parents [2]. These social trends combined with effective birth control and a greater range of treatments for infertility have resulted in a steadily expanding population of women who become pregnant after the age of 35. Pregnant women aged over 40 are no longer uncommon [3], and the question is now whether advanced maternal age increases the risk of pregnancy and results in poorer obstetrical outcomes.

However, scientific publications on this subject are rare. Most studies which classify women's age as an independent risk factor view older women as homogeneous group and neglect the differences in health and educational and socioeconomic status. A closer look does, however, reveal several prototypical groups of women who decide to become pregnant beyond the age of 40 . Some previously focused on their academic career and continue their pre-conception healthy lifestyle during pregnancy $[4,5]$. Another group of older mothers required infertility treatment to become pregnant. The third group of older mothers are those who would like to have another child to achieve their desired number of children. The last group of women who become pregnant over the age of 40 consists of women living in "patchwork families", who would like to have another child with their new partner $[6,7]$. Several studies have tried to examine the relationship between maternal age and pregnancy outcome, but most studies have reported contradictory results with regard to advanced maternal age [8-11].

In view of these different maternal profiles, this work attempts to shed more light on the hypotheses surrounding older mothers, included the postulated higher risks in pregnancy and poorer obstetrical and neonatal outcomes, because the majority of pregnancies of older mothers turn out to be uncomplicated [3]. The aim of this study was therefore to evaluate delivery outcomes in a cohort of women at the extreme of maternal age and to consider the complex impact of medical and obstetrical factors on delivery outcomes.

\section{Material and Methods \\ $\nabla$}

\section{Patient cohort}

The group sample (group IV) consisted of women who were at least 40 years old at the time of delivery and who gave birth in the University Hospital of Würzburg between 2006 and 2011. For the purpose of comparison, the data of these women were compared with those of 3 control groups stratified by maternal age (group I: aged < 30 years, group II: aged 30-34 years, group III: aged 35-39 years).

\section{Data collection}

Data for the study and control groups were obtained from the delivery room logbook and from the hospital's obstetrical documentation program (SAP). The electronic records were collected and validated by trained midwives.

\section{Criteria used to define clinical parameters}

Gestational diabetes was defined as impaired glucose tolerance detected during pregnancy by a screening test (75 g OGTT: $>90 \mathrm{mg} / \mathrm{dl}$ to $\geq 180 \mathrm{mg} / \mathrm{dl}$ to $\geq 155 \mathrm{mg} / \mathrm{dl}$ ) [12]. Hypertension present at $<20$ weeks of gestation that did not progress to preeclampsia was classified as chronic hypertension. After 20 weeks of gestation, hypertensive disorders in pregnancy were categorized as gestation-induced hypertension. Very preterm birth was defined as $\leq 32$ weeks of gestation. Maternal obesity was defined as body mass index $\geq 30 \mathrm{~kg} / \mathrm{m}^{2}$ (early pregnancy). Gestational age at delivery was based on the last menstrual period and, when possible, confirmed by first-trimester ultrasound scans. For patients who underwent in vitro fertilization, gestational age was calculated from the date of embryo transfer. Low birth weight was defined as < $2500 \mathrm{~g}$; very low birth weight was defined as $<1500 \mathrm{~g}$; macrosomia was defined as birth weight $\geq 4000 \mathrm{~g}$; small for gestational age was defined as birth weight below the 10th percentile for gestational age based on local, populationbased, live-born infant birth weight curves.

\section{Statistical analysis}

Analysis was performed using the Statistical Package for the Social Sciences (SPSS version 21) software. Comparisons between age groups were done using the chi-square test for categorical variables and analysis of variance (ANOVA) for parametric variables. A probability value of $<0.05$ was considered significant. Results are reported as proportions, odds ratios (OR) and 95\% confidence intervals $(95 \% \mathrm{CI})$.

\section{Results \\ $\boldsymbol{\nabla}$}

\section{Demographic and obstetric characteristics ( $\odot$ Table 1)}

During the study period, 8799 women gave birth in our hospital; 405 (4.6\%) of these women were $\geq 40$ years old at the time of delivery. The data showing the medical history of these women and of the control groups are presented in Table 1. Rates of gestational diabetes and of pregnancy-induced hypertension were significantly higher in the study group compared with the overall rates in the control groups ( 12.3 vs. $7.9 \%$ and 2.0 vs. $0.8 \%$, $\mathrm{p}<0.01$ for both). Maternal obesity was similar across all maternal age groups. Compared with the group "maternal age $<30$ years", significantly fewer women aged $\geq 40$ years smoked during pregnancy. There was also a stepwise increase in the rates of women who had treatment for infertility. The preeclampsia rate was higher in the study group (3.7 vs. $2.1 \%$ ). 
Table 1 Demographic and obstetric characteristics of the study and control groups.

\begin{tabular}{|c|c|c|c|c|c|c|}
\hline Variable & $\begin{array}{l}\text { Overall } \\
\text { n (\%) }\end{array}$ & $\begin{array}{l}\text { Group I } \\
\text { (<30 y) } \\
\mathrm{n}(\%)\end{array}$ & $\begin{array}{l}\text { Group II } \\
(30-34 \text { y) } \\
n(\%)\end{array}$ & $\begin{array}{l}\text { Group III } \\
(35-39 \text { y) } \\
\text { n (\%) }\end{array}$ & $\begin{array}{l}\text { Group IV } \\
\text { ( } \geq 40 \text { y) } \\
n(\%)\end{array}$ & p-value \\
\hline Number of participants & 8799 & 3433 & 3157 & 1804 & 405 & \\
\hline Nulliparity & $4515(51.3)$ & $2252(65.6)$ & $1494(47.3)$ & $632(35.0)$ & $137(33.8)$ & $<0.001$ \\
\hline Maternal obesity & $2860(38.1)$ & $1173(40.1)$ & $984(36.4)$ & $567(37.1)$ & $136(39.3)$ & 0.03 \\
\hline Twin pregnancy & $331(3.8)$ & $120(3.5)$ & $127(4.0)$ & $71(3.9)$ & $13(3.2)$ & 0.7 \\
\hline Previous cesarean delivery & $1166(13.3)$ & $278(8.1)$ & $450(14.3)$ & $359(19.9)$ & $79(19.5)$ & $<0.001$ \\
\hline $\begin{array}{l}\text { Treatment with assisted reproductive technology } \\
\text { in the past }\end{array}$ & $498(5.7)$ & $100(2.9)$ & $179(5.7)$ & $174(9.6)$ & $45(11.1)$ & $<0.001$ \\
\hline Chronic hypertension & $355(4.0)$ & $122(3.6)$ & $124(3.9)$ & $88(4.9)$ & $21(5.2)$ & 0.077 \\
\hline Smoking during pregnancy & $531(6.0)$ & $312(9.1)$ & $121(3.8)$ & $80(4.4)$ & $18(4.4)$ & $<0.001$ \\
\hline Gestational diabetes & $696(7.9)$ & $221(6.4)$ & $236(7.5)$ & $189(10.5)$ & $50(12.3)$ & $<0.001$ \\
\hline Preeclampsia & $187(2.1)$ & $69(2.0)$ & $62(2.0)$ & $41(2.3)$ & $15(3.7)$ & 0.13 \\
\hline Pregnancy-induced hypertension & $70(0.8)$ & $14(0.4)$ & $27(0.9)$ & $21(1.2)$ & $8(2.0)$ & $<0.001$ \\
\hline
\end{tabular}

Table 2 Mode and outcome of delivery according to maternal age.

\begin{tabular}{|c|c|c|c|c|c|c|}
\hline Variable & $\begin{array}{l}\text { Overall } \\
\text { n (\%) }\end{array}$ & $\begin{array}{l}\text { Group I } \\
(<30) \\
n(\%)\end{array}$ & $\begin{array}{l}\text { Group II } \\
(30-34) \\
\text { n (\%) }\end{array}$ & $\begin{array}{l}\text { Group III } \\
(35-39) \\
\text { n (\%) }\end{array}$ & $\begin{array}{l}\text { Group IV } \\
(\geq 40) \\
n(\%)\end{array}$ & p-value \\
\hline Nulliparity & $4515(51.3 \%)$ & 2252 (65.6\%) & $1494(47.3 \%)$ & $632(35.0 \%)$ & 137 (33.8\%) & $<0.001$ \\
\hline \multicolumn{7}{|l|}{ Delivery mode } \\
\hline Spontaneous vaginal delivery & 4630 (52.6) & $1902(55.4)$ & $1688(53.5)$ & $874(48.4)$ & $166(41.0)$ & $<0.001$ \\
\hline Vacuum extraction (nulliparity) & $323(7.2)$ & $143(6.3)$ & $121(8.1)$ & $47(7.4)$ & $12(8.8)$ & 0.186 \\
\hline Cesarean delivery (all) & $2494(28.3)$ & $848(24.7)$ & $845(26.8)$ & $628(34.8)$ & $173(42.7)$ & $<0.001$ \\
\hline - elective cesarean section (all) & $1040(11.8)$ & $342(10.0)$ & $359(11.4)$ & $253(14.0)$ & $86(21.2)$ & $<0.001$ \\
\hline - cesarean delivery (nulliparity) & $1385(30.7)$ & $595(26.4)$ & $424(29.0)$ & $275(43.5)$ & $81(59.1)$ & $<0.001$ \\
\hline - elective cesarean section (nulliparity) & $570(12.6)$ & $229(10.2)$ & $176(11.8)$ & $123(19.5)$ & $42(30.7)$ & $<0.001$ \\
\hline \multicolumn{7}{|l|}{ Indication for cesarean section } \\
\hline Breech presentation & $479(19.2)$ & $172(20.3)$ & $179(21.2)$ & $107(17.0)$ & $21(12.1)$ & 0.017 \\
\hline Multifetal gestation & $220(8.8)$ & $82(9.7)$ & $75(8.9)$ & $54(8.6)$ & $9(5.2)$ & 0.306 \\
\hline Non-reassuring fetal heart rate & $609(24.4)$ & $229(27.0)$ & $195(23.1)$ & $147(23.4)$ & $38(22.0)$ & 0.186 \\
\hline Placenta previa & $39(1.6)$ & $10(1.2)$ & $10(1.2)$ & $16(2.5)$ & $3(1.7)$ & 0.133 \\
\hline Previous cesarean section & $530(21.3)$ & $118(13.9)$ & $198(23.4)$ & $170(27.1)$ & $44(25.4)$ & $<0.001$ \\
\hline Preeclampsia & $89(3.6)$ & $27(3.2)$ & $24(2.8)$ & $26(4.1)$ & $12(6.9)$ & 0.047 \\
\hline Hospitalization (days) & 5.56 & 5.13 & 5.62 & 5.98 & 6.89 & $<0.001$ \\
\hline$>7$ days after cesarean section & $1155(46.3)$ & $371(43.8)$ & $377(44.6)$ & $304(48.4)$ & $103(59.5)$ & $<0.001$ \\
\hline$>4$ days after normal vaginal delivery & $3866(61.3)$ & $1482(57.3)$ & $1485(64.2)$ & $744(63.3)$ & $155(66.8)$ & $<0.001$ \\
\hline
\end{tabular}

Table 3 Neonatal outcome of singleton pregnancies.

\begin{tabular}{|c|c|c|c|c|c|c|}
\hline Variable & $\begin{array}{l}\text { Overall } \\
\mathrm{n}(\%)\end{array}$ & $\begin{array}{l}\text { Group I } \\
(<30) \\
n(\%)\end{array}$ & $\begin{array}{l}\text { Group II } \\
(30-34) \\
n(\%)\end{array}$ & $\begin{array}{l}\text { Group III } \\
(35-39) \\
n(\%)\end{array}$ & $\begin{array}{l}\text { Group IV } \\
(\geq 40) \\
n(\%)\end{array}$ & p-value \\
\hline Births & 8410 & 3294 & 3011 & 1719 & 386 & \\
\hline$\geq 4000 \mathrm{~g}$ & $767(9.1)$ & 261 (7.9) & $303(10.1)$ & $161(9.4)$ & $42(10.9)$ & 0.015 \\
\hline$\leq 2500 \mathrm{~g}$ (low birth weight) & $787(9.4)$ & $322(9.8)$ & $253(8.4)$ & $168(9.8)$ & $44(11.4)$ & 0.104 \\
\hline$\leq 1500 \mathrm{~g}$ (very low birth weight) & $238(2.8)$ & $86(2.6)$ & $76(2.5)$ & $62(3.6)$ & $14(3.6)$ & 0.099 \\
\hline Very preterm birth ( $\leq 32 \mathrm{wk})$ & $236(2.8)$ & $87(2.6)$ & $79(2.6)$ & $60(3.5)$ & $10(2.6)$ & 0.294 \\
\hline $\begin{array}{l}\text { Small for gestational age } \\
\text { (birth weight }<10 \text { th percentile) }\end{array}$ & $816(9.7)$ & $363(11.0)$ & $265(8.8)$ & $144(8.4)$ & $44(11.4)$ & 0.003 \\
\hline 5-minute Apgar score $<7$ & $300(3.6)$ & $134(4.1)$ & $98(3.3)$ & $62(3.6)$ & $6(1.6)$ & 0.050 \\
\hline Hospitalization (days) & 2.91 & 2.69 & 2.97 & 3.07 & 3.53 & $<0.001$ \\
\hline Transfer to pediatric clinic & $2516(29.9)$ & $1005(30.5)$ & $866(28.8)$ & $515(30.0)$ & $130(33.7)$ & 0.166 \\
\hline Major fetal anomalies (born alive) & $33(0.4)$ & $16(0.5)$ & $11(0.4)$ & $3(0.2)$ & $3(0.8)$ & 0.227 \\
\hline Early neonatal mortality & $35(0.4)$ & $15(0.5)$ & $9(0.3)$ & $10(0.6)$ & $1(0.3)$ & 0.477 \\
\hline
\end{tabular}


Table 4 Odds ratios for adverse pregnancy outcomes for women in the study group ( $\geq 40$ years) and one comparison group (35-39 years), compared with the $<30$ years group.

\begin{tabular}{|c|c|c|c|c|}
\hline Variable & $\begin{array}{l}\text { Group III } \\
(35-39)\end{array}$ & $\begin{array}{l}\mathrm{Cl} \\
(95 \%)\end{array}$ & $\begin{array}{l}\text { Group } \\
\text { IV }(\geq 40)\end{array}$ & $\begin{array}{l}\mathrm{Cl} \\
(95 \%)\end{array}$ \\
\hline Cesarean section (all) & 1.62 & $1.4-1.8$ & 2.27 & $1.8-2.8$ \\
\hline $\begin{array}{l}\text { Cesarean section } \\
\text { (nulliparity) }\end{array}$ & 2.14 & $1.7-2.5$ & 4.0 & $2.7-5.6$ \\
\hline $\begin{array}{l}\text { Elective cesarean } \\
\text { section (all) }\end{array}$ & 1.47 & $1.2-1.7$ & 2.43 & $1.8-3.1$ \\
\hline $\begin{array}{l}\text { Elective cesarean } \\
\text { section (nulliparity) }\end{array}$ & 2.13 & $1.6-2.7$ & 3.9 & $2.6-5.7$ \\
\hline $\begin{array}{l}\text { Prolonged hospi- } \\
\text { talization after } \\
\text { cesarean section }\end{array}$ & 1.20 & $0.9-1.4$ & 1.89 & $1.3-2.6$ \\
\hline $\begin{array}{l}\text { Prolonged hospi- } \\
\text { talization after sponta- } \\
\text { neous vaginal delivery }\end{array}$ & 1.28 & $1.1-1.4$ & 1.49 & $1.1-1.9$ \\
\hline Birth weight $\leq 2500 \mathrm{~g}$ & 0.99 & $0.8-1.1$ & 1.18 & $0.8-1.6$ \\
\hline Birth weight $\leq 1500 \mathrm{~g}$ & 1.39 & $1.0-1.9$ & 1.40 & $0.7-2.5$ \\
\hline $\begin{array}{l}\text { Small for gestational } \\
\text { age }\end{array}$ & 0.73 & $0.6-0.9$ & 1.03 & $0.7-1.4$ \\
\hline Gestational diabetes & 1.76 & $1.3-2.0$ & 1.74 & $1.4-2.8$ \\
\hline Preeclampsia & 1.13 & $0.7-1.6$ & 1.87 & $1.0-3.3$ \\
\hline Placenta previa & 3.03 & $1.4-6.2$ & 2.8 & $0.9-8.8$ \\
\hline Multifetal gestation & 1.16 & $0.8-1.5$ & 0.86 & $0.5-1.5$ \\
\hline Medical treatment & 1.35 & $1.0-1.7$ & 1.96 & $1.3-2.8$ \\
\hline Thrombosis & 1.49 & $1.0-2.0$ & 1.95 & $1.1-3.2$ \\
\hline Hypertension & 1.37 & $1.0-1.8$ & 1.48 & $0.9-2.4$ \\
\hline
\end{tabular}

\section{Mode and outcome of delivery ( $\odot$ Table 2 )}

Obstetrical data are given in $\bullet$ Table 2. Gestational age at delivery was similar across all maternal age groups. Overall, the cesarean section delivery rate for nulliparous women was significantly higher in the study group compared to the control groups (59.1 vs. $30.7 \%, \mathrm{p}<0.001$ ). The indications for cesarean section which showed the most pronounced increase between the age groups $35-39$ years and $\geq 40$ years were "previous cesarean section" and "preeclampsia" (25.4 vs. $21.3 \%, \mathrm{p}<0.001 ; 6.9$ vs. $3.6 \%$, $\mathrm{p}<0.05$ ). Furthermore, women aged $\geq 40$ years had longer hospital stays, both after cesarean section and after spontaneous delivery (59.5 vs. $46.3 \%$; 66.8 vs. $57.3 \%, \mathrm{p} \leq 0.001$ ).

\section{Neonatal outcome (๑ Table 3 )}

Fetal outcome is shown in O Table 3. 331 twins, 19 triplets and 39 stillbirths were excluded from analysis. The rate of very preterm delivery ( $\leq 32$ weeks of pregnancy) was similar across the different age groups. Birth weight $>4000 \mathrm{~g}(10.9$ vs. $9.1 \%)$ and prolonged postpartum hospitalization (3.53 vs. 2.91 days) were more common for newborns of mothers $\geq 40$ years old.

\section{Adverse pregnancy outcomes for women \\ in the study group (O Table 4)}

The odds ratios for adverse pregnancy outcomes for women in the study group ( $\geq 40$ years) and for one comparison group (3539 years) are presented in 0 Table 4 , with the group of mothers $<30$ years old used as reference. Primiparous women $\geq 40$ years old had a more than four times higher cesarean section rate and a four times higher primary cesarean section rate than mothers younger than 30 years of age. Additionally, women $\geq 40$ years old required medical treatment almost twice as often (OR: 1.96) and had an almost double risk for thrombosis (OR: 1.95) compared to mothers younger than 30 years.

\section{Discussion}

In the present study we focused on pregnant women with advanced maternal age $\geq 40$ years. Our main findings for this age group were:

1. Rates for pre-gestational chronic hypertension, gestational diabetes and pregnancy-induced hypertension were higher.

2. Nearly $43 \%$ of women $\geq 40$ years old were delivered by cesarean section. More than half of them (59.1\%) were nulliparous women. The indications for cesarean section which showed the most pronounced increases between age groups were "previous cesarean section" and "preeclampsia".

3. The study group had a prolonged hospital stay of nearly 7 days. 4. Rates for preterm delivery were similar between the age groups, but birth weight $>4000 \mathrm{~g}$ and prolonged postpartum hospitalization were increased for neonates born to women in the advanced maternal age group. No differences were detected across maternal age groups with regard to early neonatal mortality or major fetal anomalies.

Similar to our findings, some studies have reported that the number of mothers with chronic hypertension increased with advanced maternal age (starting from the age of 35 years) $[3,13$, 14]. In contrast, Cleary-Goldmann et al. did not find an increased prevalence of chronic hypertension with advanced maternal age [15].

Kanungo et al. reported that preterm neonates born to women with advanced maternal age had better odds of survival without major morbidities and a decreased risk of mortality. The following protective factors are considered to be the reason for this: use of prepartum steroids to help the baby's lungs to mature, generous indications for cesarean section, and delivery in a perinatal center. These factors could have also minimized the effects of diseases such as diabetes or hypertension [13]. These results show that older mothers tend to deliver electively, regularly attend prenatal check-ups, and protect themselves from possible complications of pregnancy.

Gestational diabetes is the most common metabolic complication of pregnancy [16-18]. In our study the risk for gestational diabetes was $74 \%$ higher for mothers $\geq 40$ years compared with mothers $<30$ years old. Yogev et al. found similar results in their Israeli study: $1.4 \%$ of $20-29$ year-olds, $4.2 \%$ of $30-39$ year-olds, $10.2 \%$ of $40-44$ year-olds and $17 \%$ of the women aged $\geq 45$ years developed gestational diabetes [19]. Cleary-Goldmann et al. found that maternal age $\geq 40$ years is an independent risk factor for the development of gestational diabetes (adjusted OR 2.4 compared to reference group $<35$ years old) [15].

In our study, mothers aged $\geq 40$ years suffered more often from pregnancy-induced hypertension than mothers in the other age groups ( 2.0 vs. $0.8 \%, \mathrm{p}<0.001$ ). Timofeev et al. found similar results in their US study: the risk of pregnancy-induced hypertension was 1.22 times higher for mothers who were $35-39.9$ years old, 1.63 times higher for mothers 40-44.9 years old and 1.89 times higher for mothers $\geq 45$ years old compared to the reference group (25-29.9 years old) [20]. Even if there is a correlation between advanced maternal age and pregnancy-induced hypertension [21], for most pregnancies this has very little impact on pregnancy outcome, although it does increase the risk of other complications like preeclampsia. Hypertension also affects the 
cardiovascular system. However, such associations are caused more often by other common predisposing risk factors than by this causal connection [21]. According to Taddei et al., endothelial dysfunction plays a significant role in the pathogenesis of atherosclerosis and hypertension [22].

In our study, the variables showing the most marked increase between age groups were "previous cesarean section" and "preeclampsia". The risk of developing preeclampsia was thus almost twice as high for mothers aged $\geq 40$ years than for mothers $<30$ years of age. (OR 1.87). The reason for this could be preexisting diseases such as diabetes or chronic hypertension which facilitate the development of preeclampsia [23-26]. Advances in reproductive techniques pose a challenge for the maternal immune system, which means a higher risk. This applies, above all, to women older than 40 years who were infertile before their first pregnancy and who underwent reproductive treatment in the past. The use of donated gametes increases the probability of developing preeclampsia [27].

Women with preeclampsia have a higher risk of developing cardiovascular disease $[28,29]$. Epigenetic changes of fetal blood vessels during pregnancy can further influence the cardiovascular system of the fetus, especially when the pregnancy is affected by preeclampsia $[30,31]$.

When we considered the mode of delivery in our cohort, $42.7 \%$ of all pregnant women aged $\geq 40$ years but only $24.7 \%$ of women aged $<30$ years delivered by cesarean section. This tendency was also seen in nulliparous women: nulliparae aged $\geq 40$ years old delivered more often by primary or secondary cesarean section ( $\mathrm{p}<0.001$ ). Karlström et al. also found a 2 to 4 times higher rate of cesarean sections in older pregnant women compared to the reference group ( $<25$ years old) (OR 4.42 for age $>35$ years and 2.05 for 25-35 years of age) [32]. Similar results were reported for an urban area by Hayles and Parisaei [33]. We found an escalation in the rates of cesarean section as maternal age increased. This phenomenon suggests that management decisions, both electively and in labor, have an important impact on cesarean section rates. They may reflect maternal preferences, obstetrician preference or a lowering of the threshold for risk avoidance $[34,35]$.

In our study, older women needed a prolonged stay in hospital, irrespective of whether delivery was by cesarean section $(>7$ days) (OR for women aged 35-39 years: 1.20; OR for women $\geq 40$ years old: 1.89 ) or by vaginal birth ( $>4$ days) (OR for women aged 35-39 years: 1.28 ; OR for women $\geq 40$ years old: 1.49 ). Klemetti et al. reported similar results in their study: women $\geq 40$ years old were more likely to be in hospital two days before the birth ( 19 vs. $12 \%$ of the $20-34$ year-old women) and had a longer (> 7 days) stay in hospital ( 9 vs. $4 \%$ of the $20-34$ year-old women) [36]. In an Israeli study by Yogev et al., mothers aged $40-44$ years (OR: 1.3 ) and mothers aged $\geq 45$ years (OR: 1.8 ) also stayed much longer in hospital ( $>7$ days) compared to 20-29 year-old mothers [19].

In our study postpartum hospitalization of neonates born to mothers $\geq 40$ years of age was longer than that of other neonates ( 3.53 vs. 2.92 days, $\mathrm{p}<0.001$ ). The percentage of transfers to the pediatric clinic was similar between the maternal age groups. Zasloff et al. mentioned a higher transfer rate to the pediatric clinic in their Swedish study: neonates of 35-43 year-old mothers had to be transferred to the pediatric clinic more often than neonates born to 26-29 year-old mothers [37]. Aasheim et al. reported that women aged $\geq 32$ years had fewer psychological problems than younger mothers in situations which required the transfer of their child to the pediatric clinic [38]. Similar to our results, Yogev et al. calculated that children born to mothers aged $\geq 40$ years had much longer hospital stays than children born to younger mothers [19]. This might be explained by the increased cesarean section rate of $\geq 40$ year-old mothers. The longer maternal hospitalization time prolongs the time spent by the child in hospital, especially as mother and child will usually leave the hospital together.

The preterm birth ( $\leq 32$ weeks) rate was similar across our study groups, and even early neonatal mortality was not higher in the children born to older mothers. In the Canadian study by Kanungo et al., the perinatal mortality of preterm neonates aged $<33$ weeks decreased with increasing maternal age [13]. Lisonkova et al. found that twins delivered by older mothers had no higher risk of perinatal mortality (preterm birth $<33$ weeks or $<28$ weeks). They even found an inverse relationship between the neonatal outcome of preterm births born at $<33$ weeks of gestation and maternal age: the older the mother, the less likely the children was to suffer from necrotizing enterocolitis, serious neurological illnesses or nosocomial infections [39].

One explanation might be that younger mothers are more likely to have infections or stress which can cause preterm delivery, whereas older mothers attend prenatal check-ups more regularly [13]. The variables influencing prematurity are complex and multifactorial. Smoking, a major risk factor for preterm birth, plays a very significant role in the preterm births of younger mothers [40]. In our study group, $9.1 \%$ of mothers $<30$ years but only $4.4 \%$ of mothers $\geq 40$ years smoked during pregnancy. Salihu et al. found similar results in their study: $11.4 \%$ of $20-29$ year-old mothers smoked while pregnant compared to $7.5 \%$ of $40-49$ year-old mothers [23]. When they compared the years 20072011 with the data for 1995-1997, Scholz et al. noted a decrease in the number of pregnant women smoking and an increase in maternal age [41]. These results could be explained by the higher socioeconomic status and education of older mothers, their work in academic professions and their more disciplined behavior during pregnancy, including a healthy lifestyle to ensure optimum nutrition of the fetus: healthy diet, avoidance of smoking and alcohol, enough sleep and physical activity. These older mothers are often better prepared for pregnancy and to raise children [42].

\section{Conclusions \\ $\nabla$}

To summarize the results of this retrospective study: there were no significant differences in pregnancy outcomes or obstetrical and neonatal outcomes between older and younger mothers, provided that (especially older) mothers were careful to treat their preexisting chronic disease medically or dietetically, have any pregnancy-induced morbidity monitored regularly or controlled medically, regularly attended prenatal check-ups, continued their healthy lifestyle during pregnancy, and delivered in a perinatal center. In accordance with Khalil et al. [43] we therefore propose an individualized patient- and disease-specific approach to prenatal care offered to pregnant women with advanced maternal age.

\section{Conflict of Interest}

$\nabla$

None. 


\section{References}

1 Heino A, Gissler M. The statistics on assisted fertility treatments. Helsinki: THL 2012 (The National Institute for Health and Welfare)

2 Bertram H, Bujard M, Rösler W. Rush-hour des Lebens: Geburtenaufschub, Einkommensverläufe und familienpolitische Perspektiven. Journal für Reproduktionsmedizin und Endokrinologie 2011; 8: 91-99

3 Cohen W. Does maternal age affect pregnancy outcome? BJOG 2014; 121: $252-254$

4 Newburn-Cook CV, Onyskiw JE. Is older maternal age a risk factor for preterm birth and fetal growth restriction? A systematic review. Health Care Women Int 2005; 26: 852-875

5 Tough SC, Newburn-Cook C, Johnston DW et al. Delayed childbearing and its impact on population rate changes in lower birth weight, multiple birth, and preterm delivery. Pediatrics 2002; 109: 399-403

6 Ritzinger P. Mutterschaft mit 40 - ovarielle Reserve und Risiken. Gynäkologe 2013; 46: 29-36

7 Ritzinger P, Dudenhausen JW, Holzgreve W. Späte Mutterschaft und deren Risiken. J Reproduktionsmed Endokrinol 2011; 8: 112-122

8 Huang L, Sauve R, Birkett $N$ et al. Maternal age and risk of stillbirth: a systematic review. CMAJ 2008; 178: 165-172

9 Joseph KS, Allen AC, Dodds L et al. The perinatal effects of delayed childbearing. Obstet Gynecol 2005; 105: 1410-1418

10 Bianco A, Stone J, Lynch L et al. Pregnancy outcome at age 40 and older. Obstet Gynecol 1996; 87: 917-922

11 Wang Y, Tanbo T, Abyholm T et al. The impact of advanced maternal age and parity on obstetric and perinatal outcomes in singleton gestations. Arch Gynecol Obstet 2011; 284: 31-37

12 Metzger BE, Gabbe SG, Persson B et al. International association of diabetes and pregnancy study groups recommendations on the diagnosis and classification of hyperglycemia in pregnancy. Diabetes Care 2010; 33: $676-682$

13 Kanungo J, James A, McMillan D et al. Advanced maternal age and the outcomes of preterm neonates: a social paradox? Obstet Gynecol 2011; 118: 872-877

14 Usta IM, Nassar AH. Advanced maternal age. Part I: obstetric complications. Am J Perinatol 2008; 25: 521-534

15 Cleary-Goldman J, Malone FD, Vidaver J et al. Impact of maternal age on obstetric outcome. Obstet Gynecol 2005; 105 (5 Pt 1): 983-990

16 Kjos SL, Buchanan TA. Gestational diabetes mellitus. N Engl J Med 1999; 341: 1749-1756

17 Di Cianni G, Volpe L, Lencioni C et al. Prevalence and risk factors for gestational diabetes assessed by universal screening. Diabetes Res Clin Pract 2003; 62: 131-137

18 Kleinwechter H. Gestationsdiabetes. Neue Leitlinie Schwangerschaftsdiabetes - Sichtweise des Diabetologen. Geburtsh Frauenheilk 2013; 73: $110-113$

19 Yogev Y, Melamed N, Bardin R et al. Pregnancy outcome at extremely advanced maternal age. Am J Obstet Gynecol 2010; 203: 558.e1-558. e7

20 Timofeev J, Reddy UM, Huang C et al. Obstetric complications, neonatal morbidity, and indications for cesarean delivery by maternal age. Obstet Gynecol 2013; 122: 1184-1195

21 Balasch J, Gratacos E. Delayed childbearing: effects on fertility and the outcome of pregnancy. Fetal Diagn Ther 2011; 29: 263-273

22 Taddei S, Virdis A, Ghiadoni L et al. Endothelium, aging, and hypertension. Current Science Inc 2006; 8: 84-89

23 Salihu HM, Shumpert MN, Slay M et al. Childbearing beyond maternal age 50 and fetal outcomes in the United States. Obstet Gynecol 2003; 102 (5 Pt 1): 1006-1014

24 Berkowitz GS, Skovron ML, Lapinski RH et al. Delayed childbearing and the outcome of pregnancy. N Engl J Med 1990; 322: 659-664
25 Simchen MJ, Yinon Y, Moran 0 et al. Pregnancy outcome after age 50. Obstet Gynecol 2006; 108: 1084-1088

26 Callaway LK, Lust K, McIntyre HD. Pregnancy outcomes in women of very advanced maternal age. Aust N Z J Obstet Gynaecol 2005; 45: 12 16

27 Wang JX, Knottnerus A, Schuit G et al. Surgically obtained sperm, and risk of gestational hypertension and pre-eclampsia. Lancet 2002; 359: 673-674

28 Bellamy L, Casas J, Hingorani AD et al. Pre-eclampsia and risk of cardiovascular disease and cancer in later life: systematic review and metaanalysis. BMJ 2007; 335: 974

29 Maas R, Baschat A, Hecher $K$ et al. Asymmetrisches Dimethylarginin (ADMA): Ein endogener Hemmstoff der NO-Synthase - und auch ein Risikomarker der Präeklampsie? Geburtsh Frauenheilk 2007; 67: 611-619

30 Nafee TM, Farrell WE, Carroll WD et al. Epigenetic control of fetal gene expression. BJOG 2008; 115: 158-168

31 Krause B, Sobrevia L, Casanello P. Epigenetics: new concepts of old phenomena in vascular physiology. CVP 2009; 7: 513-520

32 Karlstrom A, Lindgren H, Hildingsson I. Maternal and infant outcome after caesarean section without recorded medical indication: findings from a Swedish case-control study. BJOG 2013; 120: 479-486; discussion 486

33 Hayles J, Parisaei M. PLD.06 Obstetric outcomes of pregnancies in women over 40 years of age in an inner London hospital. Arch Dis Child Fetal Neonatal Ed 2014; 99 (Suppl. 1): A107

34 Vaughan DA, Cleary BJ, Murphy DJ. Delivery outcomes for nulliparous women at the extremes of maternal age - a cohort study. BJOG 2014; 121: 261-268

35 Reiter B, Windbichler G. Motive für den Wunsch nach einer electiven Sectio ohne medizinische Indikation. Geburtsh Frauenheilk 2010; 70: 28

36 Klemetti R, Gissler M, Sainio S et al. Associations of maternal age with maternity care use and birth outcomes in primiparous women: a comparison of results in 1991 and 2008 in Finland. BJOG 2014; 121: 356362

37 Zasloff E, Schytt E, Waldenstrom U. First time mothers' pregnancy and birth experiences varying by age. Acta Obstet Gynecol Scand 2007; 86: $1328-1336$

38 Aasheim $V$, Waldenstrom U, Hjelmstedt A et al. Associations between advanced maternal age and psychological distress in primiparous women, from early pregnancy to 18 months postpartum. BJOG 2012; 119: 1108-1116

39 Lisonkova S, Sheps SB, Janssen PA et al. Effect of older maternal age on birth outcomes in twin pregnancies: a population-based study. J Perinatol 2011; 31: 85-91

40 Kyrklund-Blomberg NB, Granath F, Cnattingius S. Maternal smoking and causes of very preterm birth. Acta Obstet Gynecol Scand 2005; 84 $572-577$

41 Scholz R, Voigt M, Schneider $K$ et al. Analysis of the German perinatal survey of the years 2007-2011 and comparison with data from 19951997: maternal characteristics. Geburtsh Frauenheilk 2013; 73: 1247 1251

42 Cnattingius S, Lambe $M$. Trends in smoking and overweight during pregnancy: prevalence, risks of pregnancy complications, and adverse pregnancy outcomes. Semin Perinatol 2002; 26: 286-295

43 Khalil A, Syngelaki A, Maiz $N$ et al. Maternal age and adverse pregnancy outcome: a cohort study. Ultrasound Obstet Gynecol 2013; 42: 634643 